Article

\title{
The Effect of Ag Addition on the Enhancement of the Thermal and Mechanical Properties of CuZrAl Bulk Metallic Glasses
}

\author{
Tsan-Man Chung, Sheng-Rui Jian and Pei-Ju Hsieh * \\ Department of Materials Science and Engineering, I-Shou University, Kaohsiung 84001, Taiwan; \\ isu10107008m@isu.edu.tw (T.-M.C.); srjian@isu.edu.tw (S.-R.J.) \\ * Correspondence: pjhsieh@isu.edu.tw; Tel.: +886-7-6577711 (ext. 3120)
}

Academic Editor: Ralph E. Napolitano

Received: 3 July 2016; Accepted: 1 September 2016; Published: 7 September 2016

\begin{abstract}
In this study, the thermal and mechanical properties of $\mathrm{Cu}_{50-} \mathrm{Zr}_{43} \mathrm{Al}_{7} \mathrm{Ag}_{x}(x=0,3,4,5,6)$ bulk metallic glasses (BMGs) are investigated by using an X-ray diffractometer (XRD), a differential scanning calorimeter (DSC), differential thermal analysis (DTA), a Vickers hardness tester, a material test system (MTS), scanning electron microscopy (SEM), and transmission electron microscopy (TEM). $\mathrm{Cu}_{50-x} \mathrm{Zr}_{43} \mathrm{Al}_{7} \mathrm{Ag}_{x}(x=0,3,4,5,6)$ BMGs were made by arc-melting and an injection casting process. The results revealed that the glass transition temperature $\left(T_{\mathrm{g}}\right)$ and the crystallization temperature $\left(T_{\mathrm{x}}\right)$ of $\mathrm{CuZrAl}$ alloy decreased with the Ag addition. Hence, the supercooled liquid region and $\gamma$ of $\mathrm{Cu}_{45} \mathrm{Zr}_{43} \mathrm{Al}_{7} \mathrm{Ag}_{5}$ alloy increased to $76 \mathrm{~K}$ and 0.42 , respectively. The thermal stability and glass forming ability of CuZrAlAg BMG alloys were enhanced by the microalloyed Ag content. The room temperature compressive fracture strength and strain measured of $\mathrm{Cu}_{47} \mathrm{Zr}_{43} \mathrm{Al}_{7} \mathrm{Ag}_{3}$ were about $2200 \mathrm{MPa}$ and $2.1 \%$, respectively. The distribution of vein patterns and the formation of nanocrystalline phases on the fracture surface of $\mathrm{Cu}_{47} \mathrm{Zr}_{43} \mathrm{Al}_{7} \mathrm{Ag}_{3}$ alloy can be observed by SEM and TEM to be significant, indicating a typical ductile fracture behavior and an improved plasticity of alloys with the addition of microalloyed Ag from 0 to 6 atom \%.
\end{abstract}

Keywords: bulk metallic glasses; vein patterns; plasticity

\section{Introduction}

$\mathrm{Cu}-\mathrm{Zr}$-Al bulk metallic glasses (BMGs) with low density have attracted increasing attention due to their high specific strength and density ratio and excellent thermal properties [1-6], as compared with the conventional alloys. For example, the $\mathrm{Cu}_{45} \mathrm{Zr}_{48} \mathrm{Al}_{7} \mathrm{BMGs}$ [7] exhibits high fracture stress near $1890 \mathrm{MPa}$. Hence, the development of $\mathrm{Cu}$-based bulk amorphous alloys in structural parts and the transportation vehicle applications is steadily growing. However, the low workability at room temperature of $\mathrm{Cu}$-based BMGs has limited their applications [7]. Therefore, the enhancement on the plasticity of BMGs with high glass forming ability (GFA) has been strongly requested.

The ductility of BMGs can be solved effectively by the addition of a selected element. Therefore, a positive heat of mixing with the major constituent elements of the base alloys has been reported to increase the room temperature plasticity of BMGs [8-14]. For example, $\mathrm{Cu}_{46} \mathrm{Zr}_{45} \mathrm{Al}_{7} \mathrm{Y}_{2}$ (Zr-Y: $+35 \mathrm{~kJ} / \mathrm{mol}), \mathrm{Cu}_{45} \mathrm{Zr}_{47} \mathrm{Al}_{7} \mathrm{Fe}_{1}(\mathrm{Cu}-\mathrm{Fe}:+13 \mathrm{~kJ} / \mathrm{mol})$, and $\mathrm{Cu}_{43} \mathrm{Zr}_{43} \mathrm{Al}_{7} \mathrm{Ag}_{7}(\mathrm{Cu}-\mathrm{Ag}:+5 \mathrm{~kJ} / \mathrm{mol})$ exhibited the enhanced plastic strain of $5.21 \%, 9.48 \%$, and $6.3 \%$, respectively [15-17]. Much research has shown that the adding of $\mathrm{Ag}$ can effectively enhance the GFA of the $\mathrm{Cu}-\mathrm{Zr}-, \mathrm{Zr}-\mathrm{Cu}-, \mathrm{Zr}-\mathrm{Cu}$-Al-based BMGs [18-24].

In this study, the $\mathrm{Cu}_{50} \mathrm{Zr}_{43} \mathrm{Al}_{7}$ [25] with high GFA and high thermal stability are used as base alloys, and the structural transformations and the shear deformation process of BMGs are studied 
by microalloyed Ag content. Variations in thermal and mechanical properties of $\mathrm{Cu}_{50-x} \mathrm{Zr}_{43} \mathrm{Al}_{7} \mathrm{Ag}_{x}$ BMGs made with microalloyed Ag content (from 0 to 6 atom \%) are discussed in conjunction with the analysis of XRD, DSC, DTA, micro-hardness, and compression stress-strain curves of measured BMGs.

\section{Materials and Methods}

The composition of $\mathrm{Cu}_{50-x} \mathrm{Zr}_{43} \mathrm{Al}_{7} \mathrm{Ag}_{x}(x=0,3,4,5$, and 6 in the following denoted as Ag0, Ag3, Ag4, Ag5, and Ag6) were selected for preparing the bulk metallic glasses (BMGs). High purity elements (>99.9 wt. \% or higher) were pre-alloyed into an alloy ingot by an arc melting process in a Ti-gettered argon atmosphere. Alloy ingots were remelted five times to ensure chemical homogeneity. BMG rod specimens with diameters of 2-3 $\mathrm{mm}$ were fabricated by suction casting into a water-cooled $\mathrm{Cu}$ mold under an argon atmosphere. Differential scanning calorimeter (TA Instruments DSC 2920, TA Instruments Inc., New Castle, DE, USA) and differential thermal analysis (Perkin Elmer DTA-7, PerkinElmer Inc., Waltham, MA, USA) were used for thermal analyses of the specimens at a heating rate of $20 \mathrm{~K} / \mathrm{min}$. Hardness measurements and compression tests were performed with a Vickers hardness tester (Akashi AVK-C2, Akashi Corporation, Kanagawa, Japan) and the MTS 810 material test system at room temperature (at a strain rate of $1 \times 10^{-4}$ ). Cylindrical samples with the height-to-diameter ratio of 2:1 were cut from as-cast rods. Structural characterization was examined with an X-ray diffractometer (XRD, Sintage X-4000, with monochromatic $\mathrm{Cu}-\mathrm{K} \alpha$ radiation), scanning electron microscopy (SEM, Hitachi S-3400, Hitachi High-Technologies Corporation, Tokyo, Japan), and transmission electron microscopy (TEM, FEI, Tecnai G2 20 S-Twin, FEI company, FEI company, OR, USA).

\section{Results and Discussion}

\subsection{Phase Identification}

The XRD patterns of $\mathrm{Cu}_{50-x} \mathrm{Zr}_{43} \mathrm{Al}_{7} \mathrm{Ag}_{x}(x=0,3,4,5,6)$ alloys are shown in Figure 1 . Within the limit of XRD resolution, the XRD spectra reveal broad diffraction humps without any characteristic Bragg peaks corresponding to crystalline phases. The verification of $\mathrm{Cu}_{50-x} \mathrm{Zr}_{43} \mathrm{Al}_{7} \mathrm{Ag}_{x}(x=0,3,4,5,6)$ alloys with the microalloyed Ag addition was achieved.

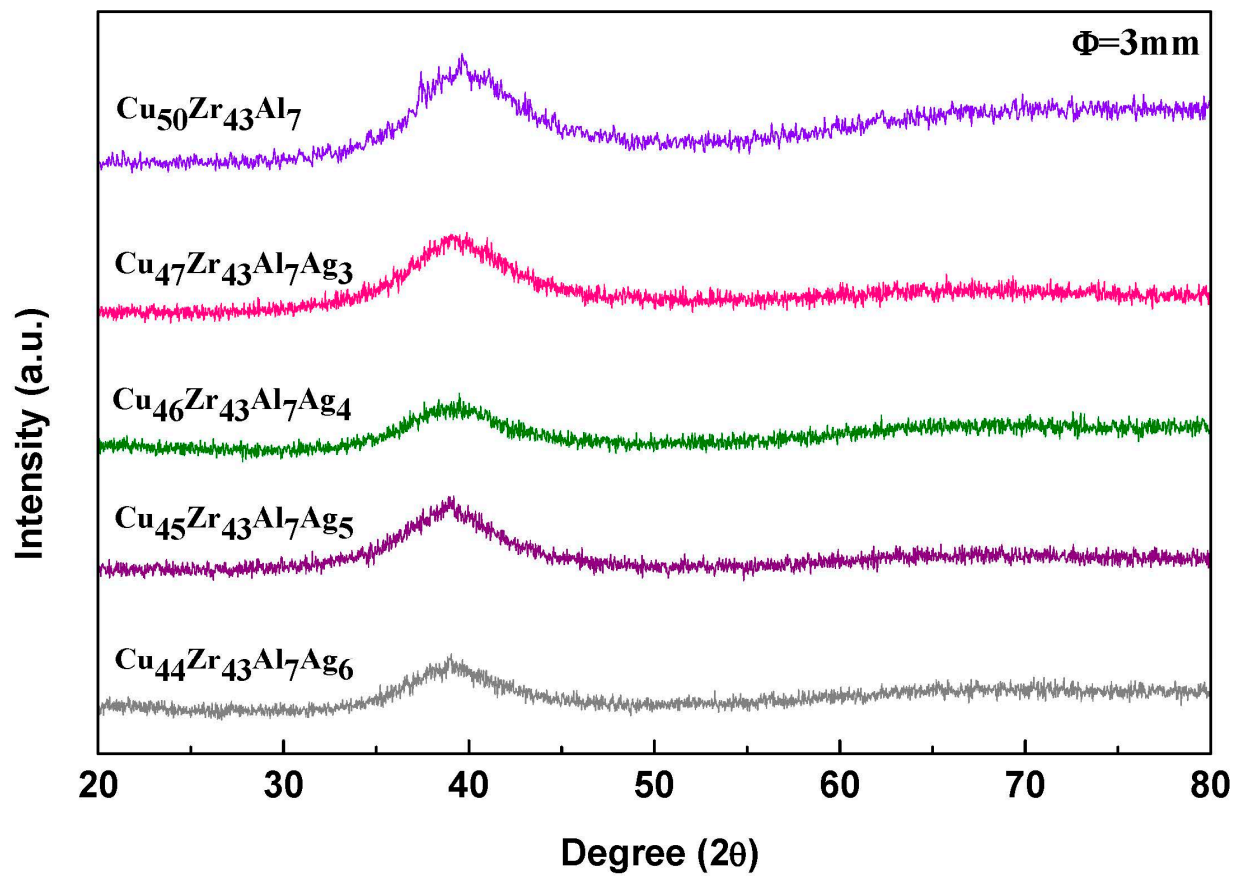

Figure 1. $\mathrm{XRD}$ patterns of the as-cast $\mathrm{Cu}_{50-x} \mathrm{Zr}_{43} \mathrm{Al}_{7} \mathrm{Ag}_{x}(x=0,3,4,5,6)$ alloys. 


\subsection{Thermal Analysis}

Figure 2 illustrates the DSC and the DTA curves of $\mathrm{Cu}_{50-x} \mathrm{Zr}_{43} \mathrm{Al}_{7} \mathrm{Ag}_{x}(x=0,3,4,5,6)$ BMGs. Their glass transition temperature $\left(T_{\mathrm{g}}\right)$, crystallization onset temperature $\left(T_{\mathrm{x}}\right)$, liquidus temperature $\left(T_{1}\right)$, and related thermal parameters are summarized in Table 1 . No obvious variation of the crystallization temperature of the alloys can be found, but both of the glass transition temperatures and the liquidus temperature of the alloys decreases with increasing Ag content. Hence, the reduced glass transition temperature $\left(T_{\mathrm{rg}}=T_{\mathrm{g}} / T_{1}\right)$ and the $\gamma$ parameter $\left(\gamma=T_{\mathrm{x}} /\left(T_{\mathrm{g}}+T_{1}\right)\right)$ increase as the content of microalloyed $\mathrm{Ag}$ increases, indicating an increment of the glass forming ability (GFA) of $\mathrm{Cu}_{50-x} \mathrm{Zr}_{43} \mathrm{Al}_{7} \mathrm{Ag}_{x}(x=0$, $3,4,5,6)$ BMGs. The supercooled liquid region $\left(\Delta T_{\mathrm{x}}=T_{\mathrm{x}}-T_{\mathrm{g}}\right)$ are extended from 54 to $76 \mathrm{~K}$ with a 5 -atom \% Ag addition; however, this region is reduced to $62 \mathrm{~K}$ as the microalloyed Ag further increases to 6 atom $\%$.

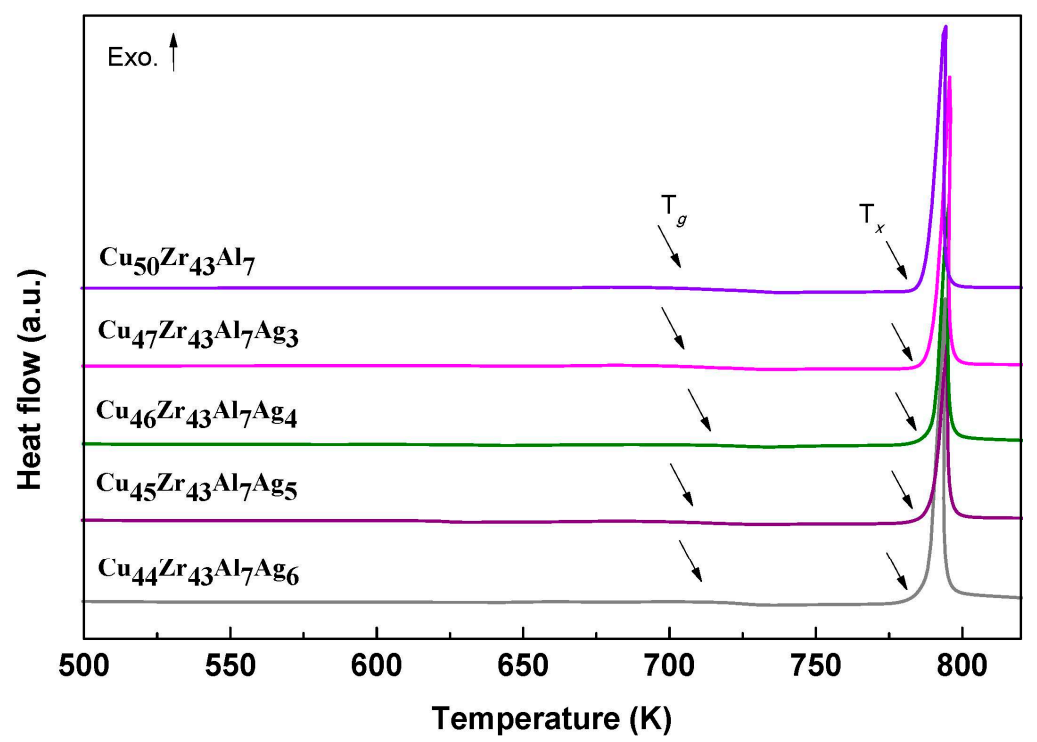

(a)

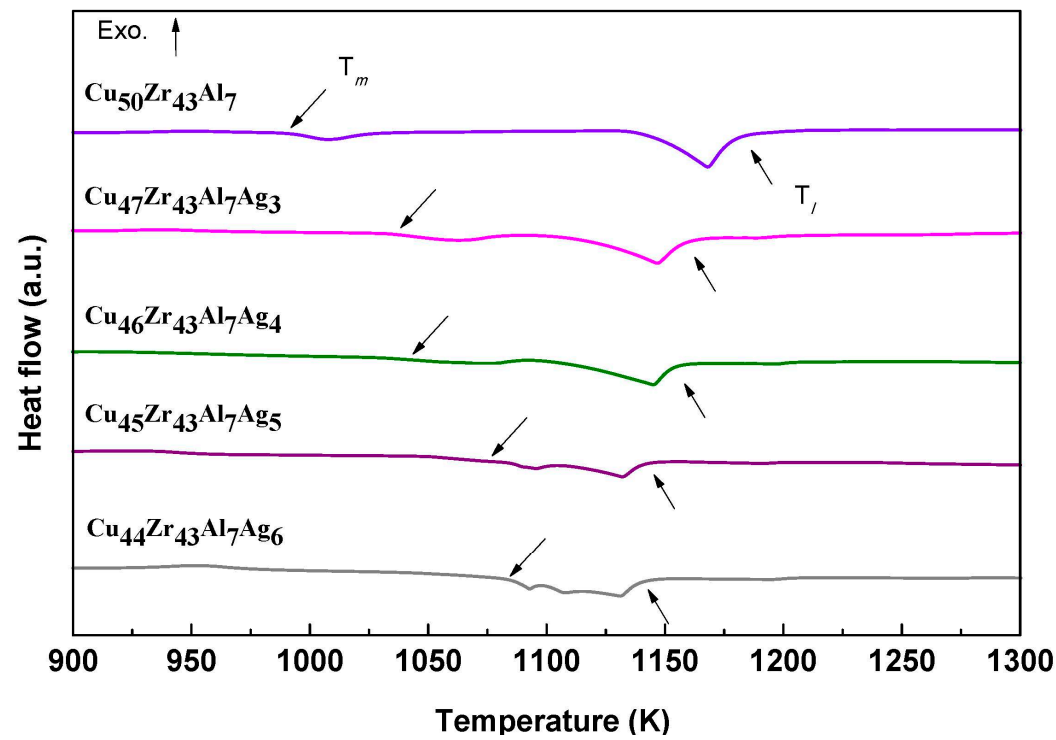

(b)

Figure 2. (a) The DSC and (b) the DTA curves of the $\mathrm{Cu}_{50-x} \mathrm{Zr}_{43} \mathrm{Al}_{7} \mathrm{Ag}_{x}(x=0,3,4,5,6) \mathrm{BMGs}$. 
Table 1. Thermal parameters of the $\mathrm{Cu}_{50-x} \mathrm{Zr}_{43} \mathrm{Al}_{7} \mathrm{Ag}_{x}(x=0,3,4,5,6) \mathrm{BMG}$ alloys measured at a heating rate of $20 \mathrm{~K} / \mathrm{min}$.

\begin{tabular}{lcccccc}
\hline Composition & $\boldsymbol{T}_{\mathbf{g}}(\mathbf{K})$ & $\boldsymbol{T}_{\mathbf{x}}(\mathbf{K})$ & $\boldsymbol{T}_{\mathbf{1}}(\mathbf{K})$ & $\Delta \boldsymbol{T}_{\mathbf{x}}(\mathbf{K})$ & $\boldsymbol{T}_{\mathbf{r g}}$ & $\gamma$ \\
\hline $\mathrm{Cu}_{50} \mathrm{Zr}_{43} \mathrm{Al}_{7}$ & 731 & 785 & 1182 & 54 & 0.62 & 0.41 \\
$\mathrm{Cu}_{47} \mathrm{Zr}_{43} \mathrm{Al}_{7} \mathrm{Ag}_{3}$ & 725 & 788 & 1164 & 63 & 0.62 & 0.42 \\
$\mathrm{Cu}_{46} \mathrm{Zr}_{43} \mathrm{Al}_{7} \mathrm{Ag}_{4}$ & 724 & 788 & 1156 & 64 & 0.63 & 0.42 \\
$\mathrm{Cu}_{45} \mathrm{Zr}_{43} \mathrm{Al}_{7} \mathrm{Ag}_{5}$ & 711 & 787 & 1142 & 76 & 0.62 & 0.42 \\
$\mathrm{Cu}_{44} \mathrm{Zr}_{43} \mathrm{Al}_{7} \mathrm{Ag}_{6}$ & 725 & 787 & 1140 & 62 & 0.64 & 0.42 \\
\hline
\end{tabular}

\subsection{Compression Tests and Microstructure Observation}

The room temperature compressive stress-strain curves of the $\mathrm{Cu}_{50-x} \mathrm{Zr}_{43} \mathrm{Al}_{7} \mathrm{Ag}_{x}$ rods are shown in Figure 3. The size of the rod samples used for the compression tests was $1 \mathrm{~mm}$ in diameter and $2 \mathrm{~mm}$ in height. As can be seen, the Ag-free base alloy with composition of $\mathrm{Cu}_{50} \mathrm{Zr}_{43} \mathrm{Al}_{7}$ exhibits less than $1 \%$ plastic strain. Vein-like patterns (as shown in Figure 4a) are displayed on the fracture surface of $\mathrm{Cu}_{50} \mathrm{Zr}_{43} \mathrm{Al}_{7}$ alloys, indicating a slightly plastic fracture behavior of this specimen. Moreover, the results presented in Figure 3 show that the alloys with Ag contents of 3 and 5 atom \% exhibit compressive plasticity and that the compressive strain increased to $2.1 \%$ and $1.5 \%$, respectively. However, we found that the plastic strain of CuZrAlAg alloys is lower than that of the base alloy when the microalloyed $\mathrm{Ag}$ content exceeds 4 atom \%. In addition, the fracture stress of the $\mathrm{CuZrAlAg}$ alloy increased to $2280 \mathrm{MPa}$ with a 3-atom \% Ag addition; however, it decreased to 1900 MPa upon further increases in the Ag content. It is observed that the strength of the $\mathrm{Cu}_{50-x} \mathrm{Zr}_{43} \mathrm{Al}_{7} \mathrm{Ag}_{x}(x=0$, $3,4,5,6)$ BMG alloys does not improve with the addition of microalloyed Ag more than 3 atom \%. The $\mathrm{Cu}_{47} \mathrm{Zr}_{43} \mathrm{Al}_{7} \mathrm{Ag}_{3} \mathrm{BMG}$ alloy exhibits the highest ductility. The variation tendency of hardness (Figure 5) is similar to that of the fracture stress of the $\mathrm{Cu}_{50-x} \mathrm{Zr}_{43} \mathrm{Al}_{7} \mathrm{Ag}_{x}(x=0,3,4,5,6)$ alloys.

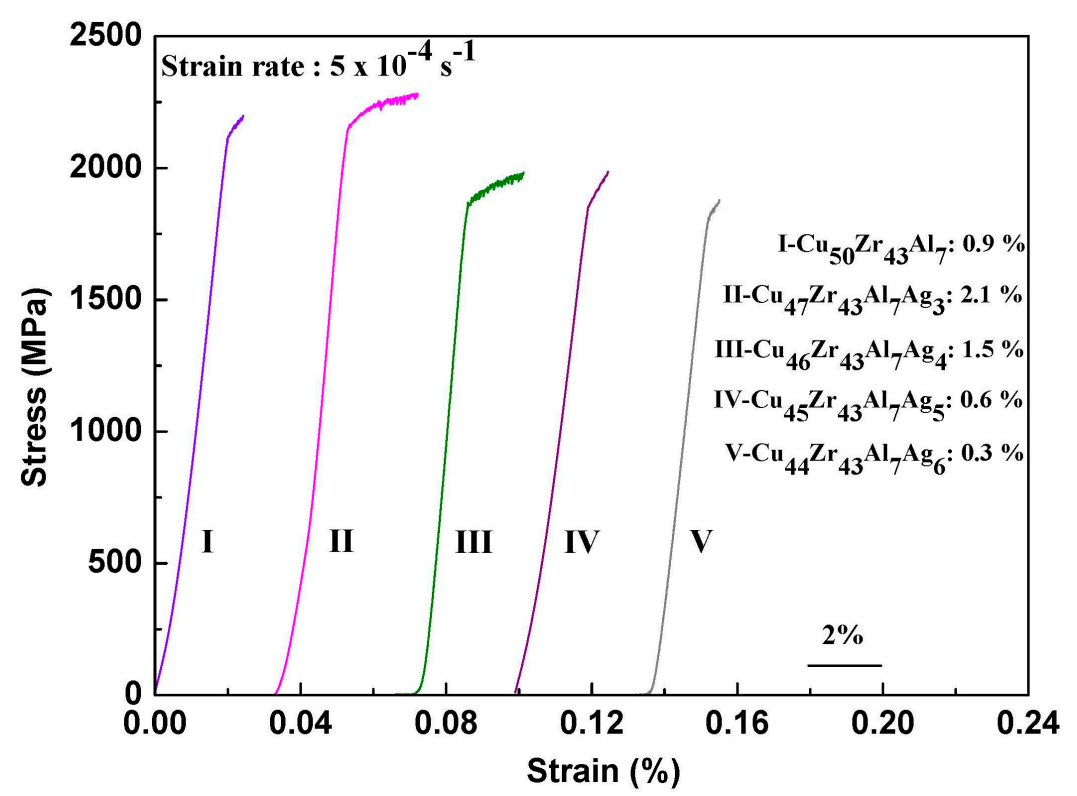

Figure 3. Compressive stress-strain curves of the $\mathrm{Cu}_{50-x} \mathrm{Zr}_{43} \mathrm{Al}_{7} \mathrm{Ag}_{x}(x=0,3,4,5,6)$ rods at room temperature. 


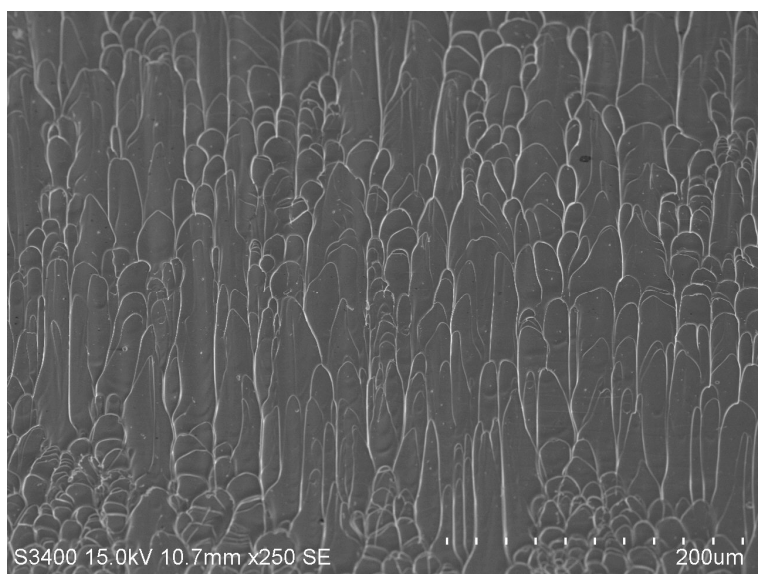

(a)

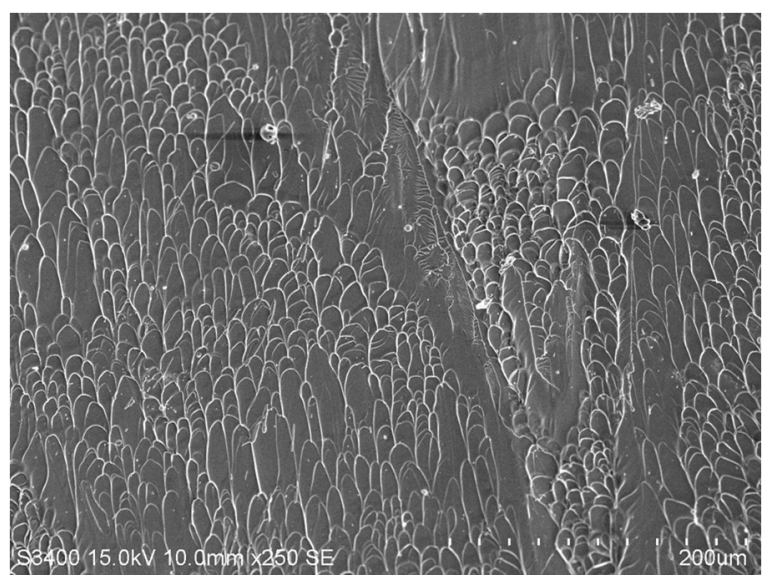

(c)

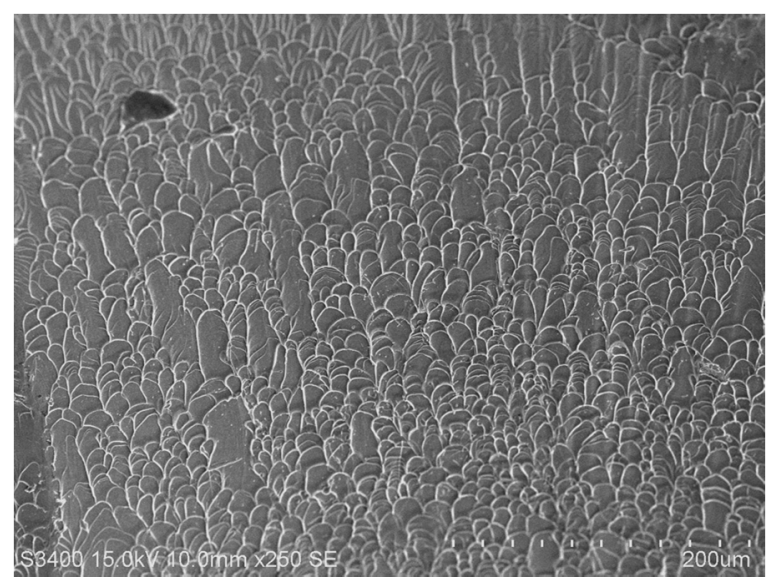

(b)

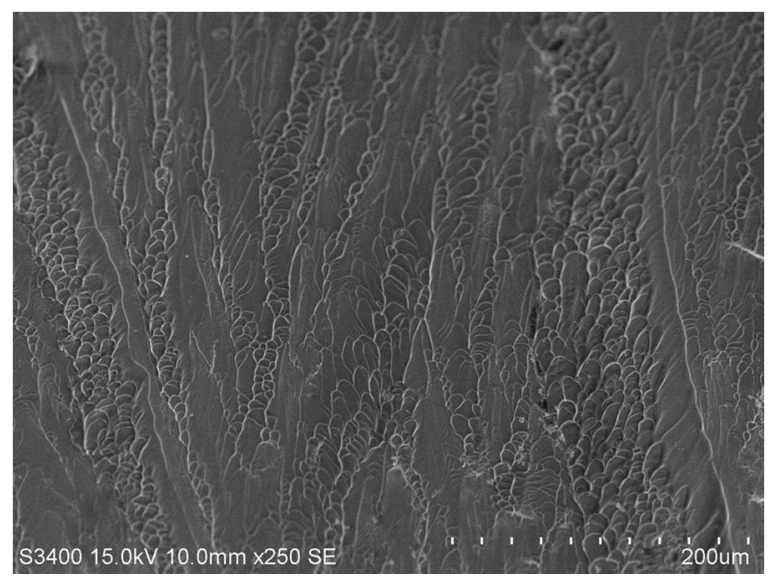

(d)

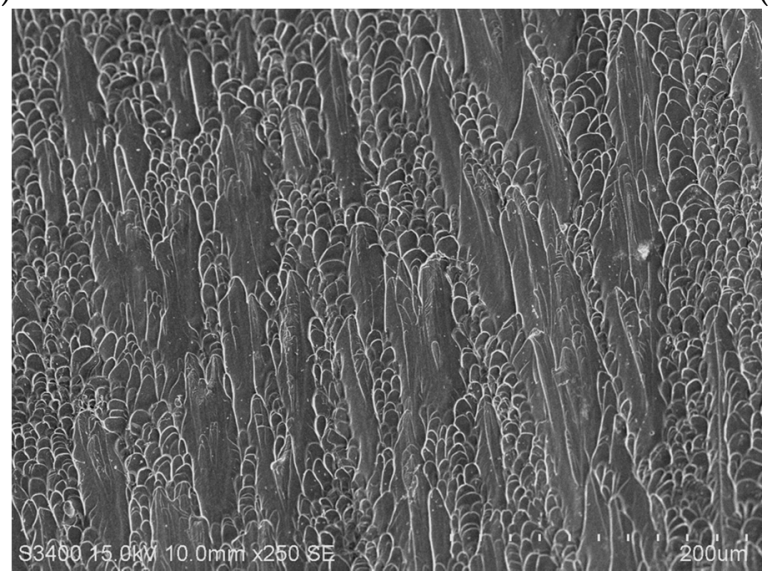

(e)

Figure 4. SEM images of the compressive fracture surface of $\mathrm{Cu}_{50-x} \mathrm{Zr}_{43} \mathrm{Al}_{7} \mathrm{Ag}_{x}$ alloys: (a) $x=0$; (b) $x=3$; (c) $x=4$; (d) $x=5$, and (e) $x=6$. 


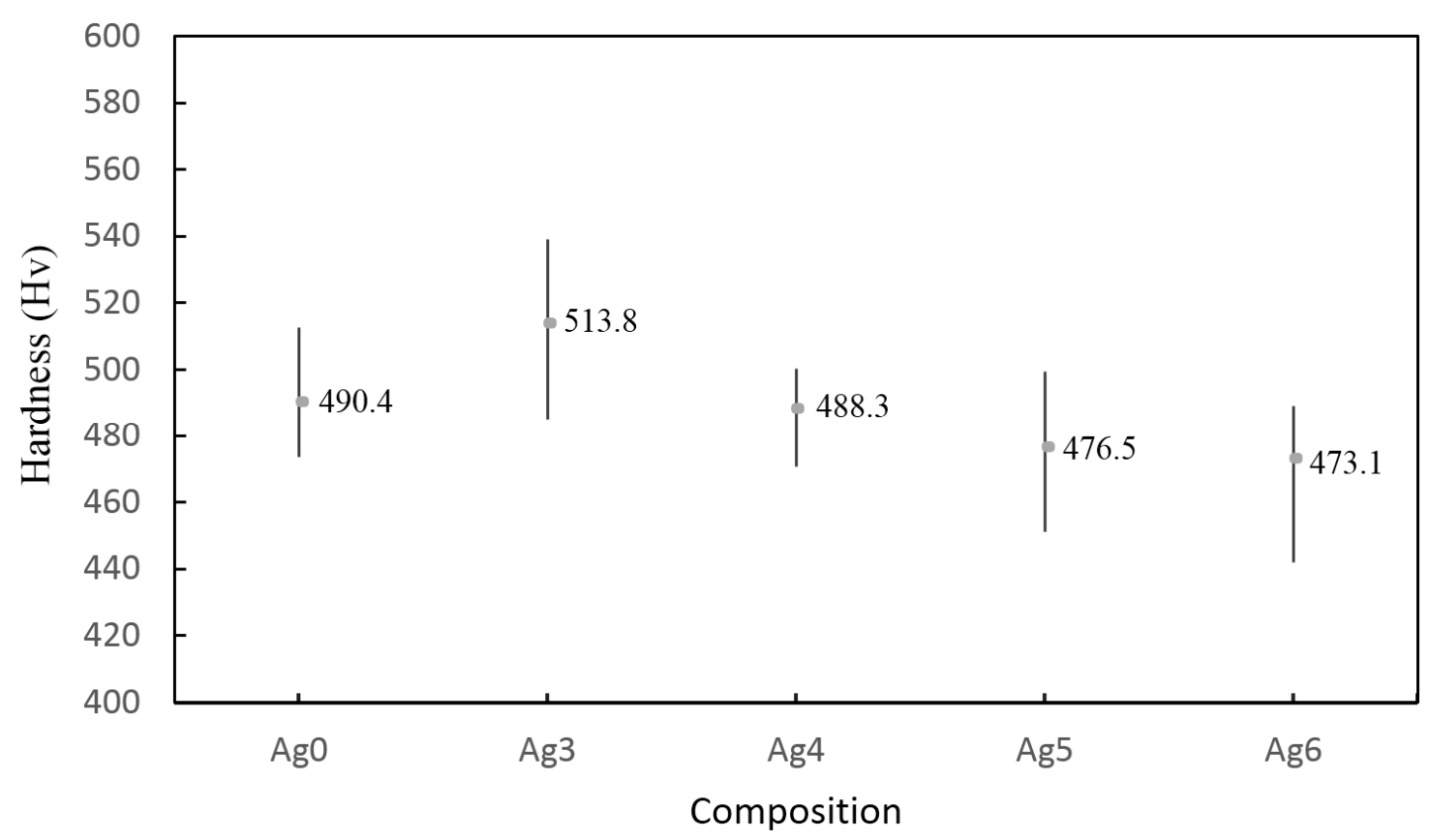

Figure 5. The hardness of the $\mathrm{Cu}_{50-x} \mathrm{Zr}_{43} \mathrm{Al}_{7} \mathrm{Ag}_{x}$ alloys with increasing microalloyed $\mathrm{Ag}$ content.

The fracture surface of a $\mathrm{Cu}_{47} \mathrm{Zr}_{43} \mathrm{Al}_{7} \mathrm{Ag}_{3}$ alloy subjected to room temperature compression is displayed in Figure $4 \mathrm{~b}$. The appearance of the vein pattern is evidence of the ductile fracture behavior in the $\mathrm{Cu}_{47} \mathrm{Zr}_{43} \mathrm{Al}_{7} \mathrm{Ag}_{3}$ alloy, suggesting that viscous flow occurs during the plastic deformation. With the increasing Ag content, the micrographs on the fracture surface of the $\mathrm{Cu}_{50-x} \mathrm{Zr}_{43} \mathrm{Al}_{7} \mathrm{Ag}_{x}(x \geq 4)$ alloys shown in Figure 4c-e indicate a gradual reduction in the regions of vein patterns with an increase in smooth areas. The smooth areas are related to the rapid propagation of the brittle fracture.

Figure 6 shows SEM images of the shear bands that occur on the lateral surface of the $\mathrm{Cu}_{50-x} \mathrm{Zr}_{43} \mathrm{Al}_{7} \mathrm{Ag}_{x}$ alloys after compressive testing. It is evident that the primary and secondary shear bands (indicated using a dashed-line arrow) are formed after the room temperature compression. In Figure $6 b-d$, the secondary shear bands interact with the primary ones and subsequently retard the propagation of the primary shear bands. However, in Figure 6e, no secondary shear bands are visible and only one set of the primary shear bands near the edge of fracture surface is formed. Therefore, the $\mathrm{Cu}_{47} \mathrm{Zr}_{43} \mathrm{Al}_{7} \mathrm{Ag}_{6}$ alloy was excluded from the calculation of shear band density. The statistical shear band density of $\mathrm{Cu}_{50-x} \mathrm{Zr}_{43} \mathrm{Al}_{7} \mathrm{Ag}_{x}(x=0,3,4,5)$ BMGs with different Ag contents are as follows. The results can be divided into two parts: a rapid increase from $4.1 \times 10^{-3} \mu^{-1}(\mathrm{Ag} 0)$ to $11.6 \times 10^{-3} \mu \mathrm{m}^{-1}\left(\mathrm{Ag} 3\right.$ ), followed by a decrease to $9.2 \times 10^{-3} \mu \mathrm{m}^{-1}$ (Ag4) and $7.2 \times 10^{-3} \mu^{-1}$ (Ag5). This suggests that the dense distribution of shear bands is related to the enhanced ductility and strength of BMGs.

The $\mathrm{Cu}_{47} \mathrm{Zr}_{43} \mathrm{Al}_{7} \mathrm{Ag}_{3} \mathrm{BMG}$ alloys possessed the largest fracture strength, hardness, and plastic strain. Therefore, they were selected for further study. SEM micrographs of the outer surface of $\mathrm{Cu}_{47} \mathrm{Zr}_{43} \mathrm{Al}_{7} \mathrm{Ag}_{3}$ rods after compressive testing showed the formation and propagation of the secondary shear bands on the lateral surface of the $\mathrm{Cu}_{47} \mathrm{Zr}_{43} \mathrm{Al}_{7} \mathrm{Ag}_{3}$ alloy, which leads to an increase in plastic strain. This result is confirmed via TEM observation. In contrast to the TEM images of $\mathrm{Cu}_{47} \mathrm{Zr}_{43} \mathrm{Al}_{7} \mathrm{Ag}_{3}$ (Figure 7a,b) and $\mathrm{Cu}_{47} \mathrm{Zr}_{43} \mathrm{Al}_{7} \mathrm{Ag}_{6}$ (Figure 7c,d) alloys shown in Figure 7, the nano-sized crystalline phase is evident from the TEM images of the $\mathrm{Cu}_{47} \mathrm{Zr}_{43} \mathrm{Al}_{7} \mathrm{Ag}_{3}$ amorphous matrix. $\mathrm{Ag}$ has a positive enthalpy of mixing with $\mathrm{Cu}(\mathrm{Cu}-\mathrm{Ag}:+5 \mathrm{~kJ} / \mathrm{mol})$, which results in the separation of the nanocrystalline phase from the liquid state of the $\mathrm{Cu}_{47} \mathrm{Zr}_{43} \mathrm{Al}_{7} \mathrm{Ag}_{3}$ alloy. The formation of a nanocrystalline phase in the BMG matrix leads to the discontinuous propagation and branching of the primary shear bands during the shear deformation [26]. Therefore, the strength, plastic strain, and hardness of the $\mathrm{Cu}_{47} \mathrm{Zr}_{43} \mathrm{Al}_{7} \mathrm{Ag}_{3}$ 
alloys are enhanced by the presence of small-sized and homogeneously scattered nanocrystals, as observed in the SEM images and in the room temperature compressive stress-strain curves of the $\mathrm{Cu}_{47} \mathrm{Zr}_{43} \mathrm{Al}_{7} \mathrm{Ag}_{3}$ alloy.

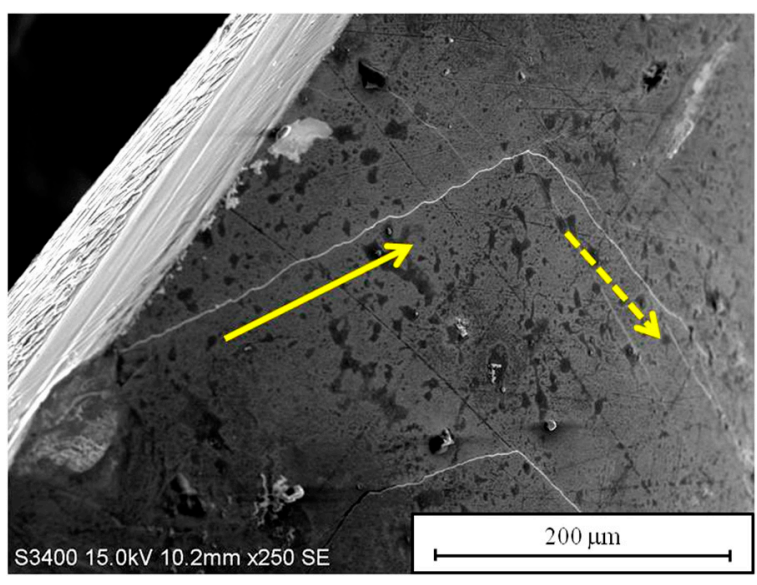

(a)

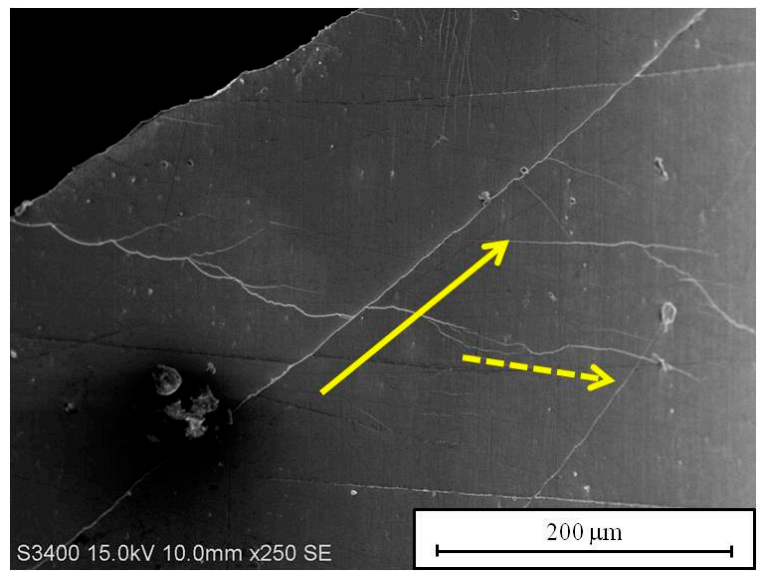

(c)

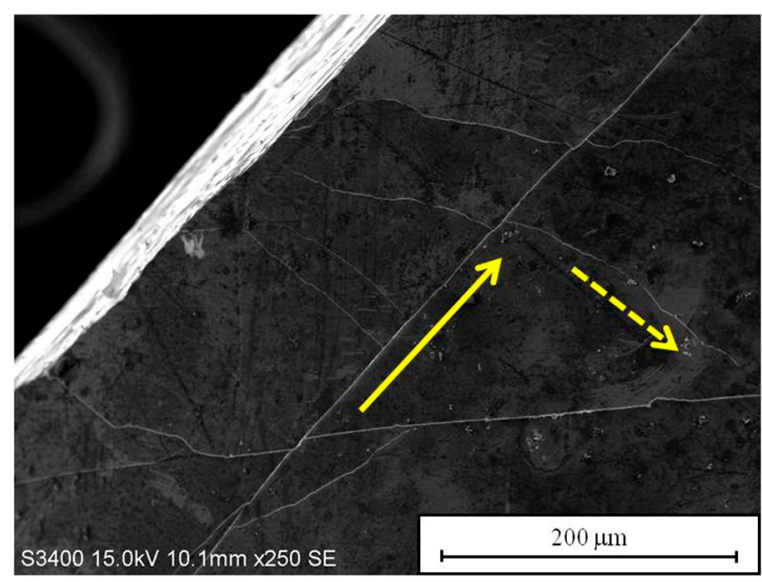

(b)

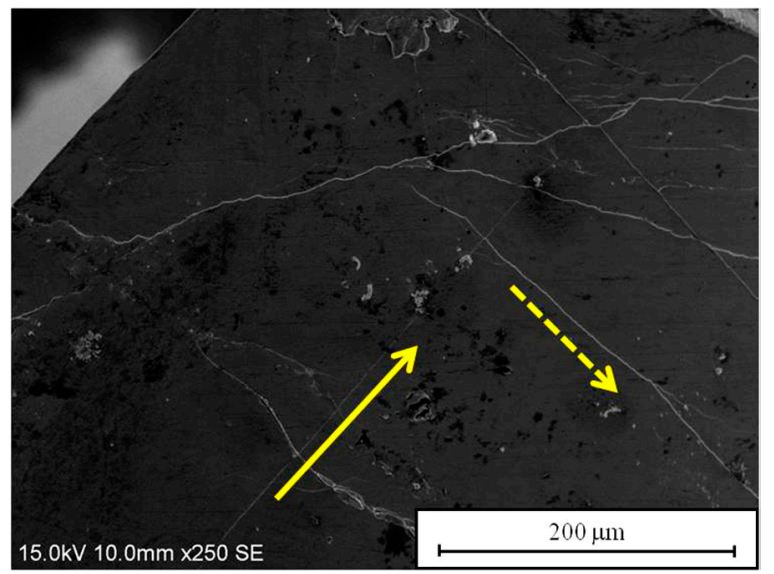

(d)

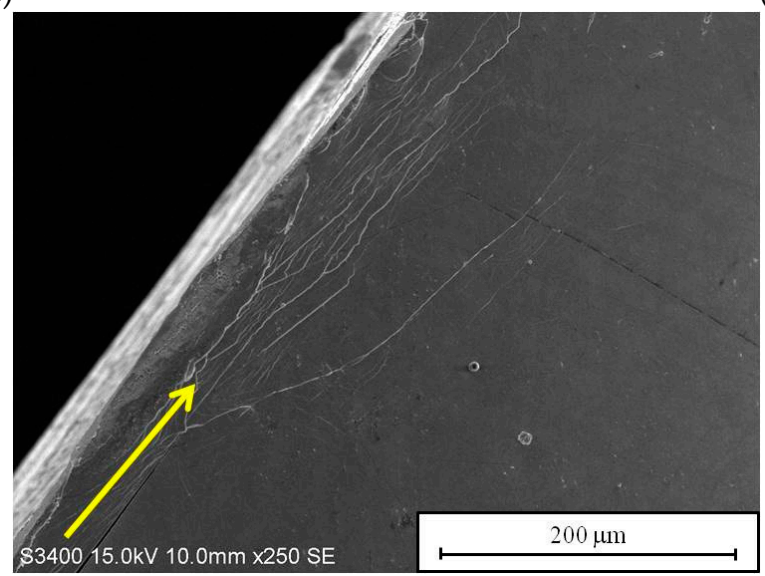

(e)

Figure 6. SEM images of the multiple shear bands on the lateral surface of compressive $\mathrm{Cu}_{50-x} \mathrm{Zr}_{43} \mathrm{Al}_{7} \mathrm{Ag}_{x}$ alloys: (a) $x=0$, (b) $x=3$, (c) $x=4$, (d) $x=5$, and (e) $x=6$. The two arrows indicated the primary shear bands and the secondary shear bands (the arrow with dashed line). 


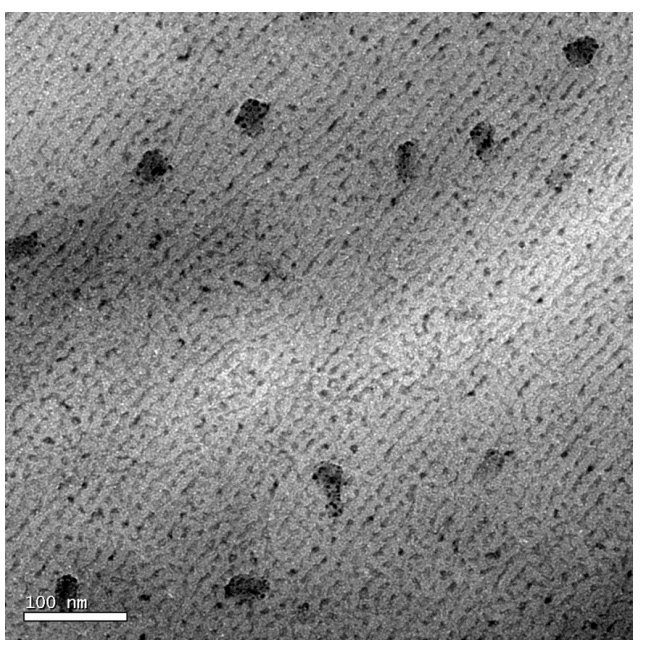

(a)

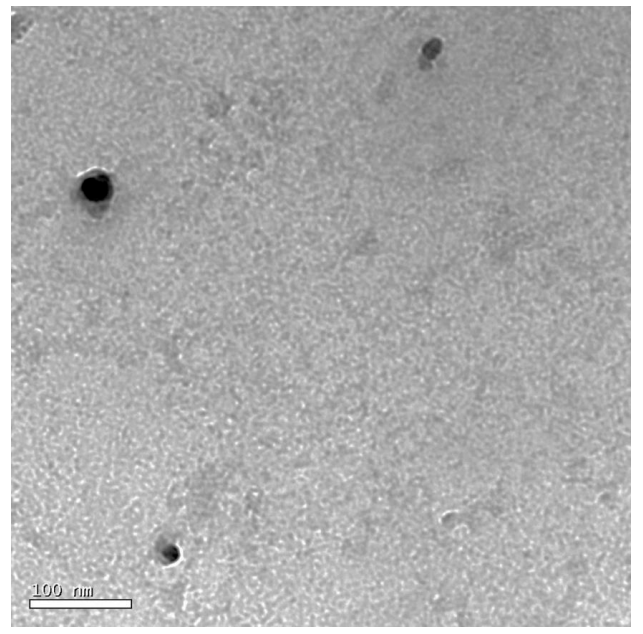

(c)

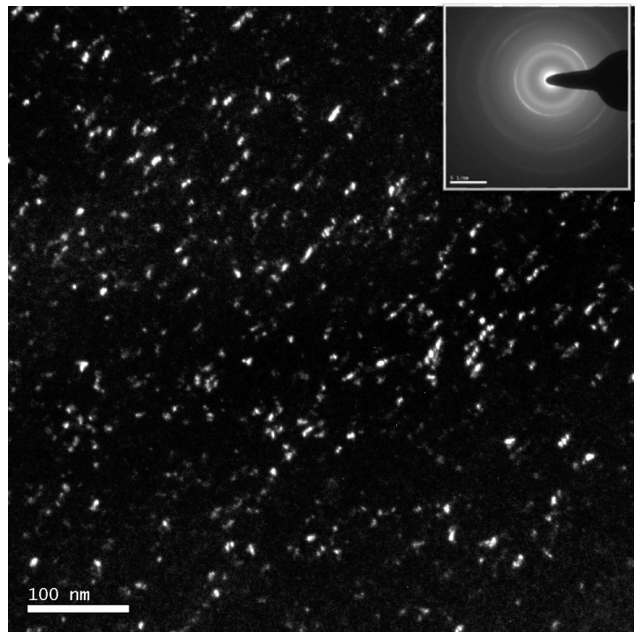

(b)

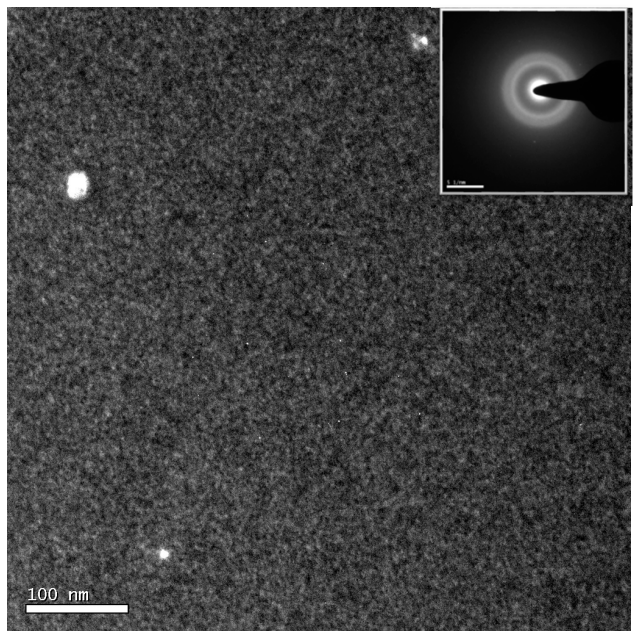

(d)

Figure 7. TEM bright field and dark field images of $\mathrm{Cu}_{47} \mathrm{Zr}_{43} \mathrm{Al}_{7} \mathrm{Ag}_{3}(\mathbf{a}, \mathbf{b})$ and $\mathrm{Cu}_{47} \mathrm{Zr}_{43} \mathrm{Al}_{7} \mathrm{Ag}_{6}$ (c,d) BMG alloys.

In contrast, the $\mathrm{Cu}_{47} \mathrm{Zr}_{43} \mathrm{Al}_{7} \mathrm{Ag}_{6}$ alloy had fewer nanocrystalline phases in the BMG matrix, which were also of larger size. Hence, the large-sized nanocrystalline phase in $\mathrm{Cu}_{47} \mathrm{Zr}_{43} \mathrm{Al}_{7} \mathrm{Ag}_{6}$ alloy is inefficient for the retarding of the shear band propagation and led to the reduction in hardness, compressive stress, and strain.

\section{Conclusion}

In conclusion, the structural, thermal, and mechanical properties of $\mathrm{Cu}_{50-x} \mathrm{Zr}_{43} \mathrm{Al}_{7} \mathrm{Ag}_{x}$ amorphous alloys with microalloyed Ag addition (from 0 to 6 atom \%) were studied by XRD, thermal analyses, a micro-hardness test, and a compression test. Results indicated that the glass forming ability ( $\gamma$ up to 0.42$)$ and the thermal stability $\left(\Delta T_{\mathrm{x}}\right.$ up to $\left.76 \mathrm{~K}\right)$ can be improved by partial substitution of $\mathrm{Cu}$ by Ag element. The higher mechanical properties with compressive fracture stress, plastic strain, and hardness near to the values of $2280 \mathrm{MPa}, 2.1 \%$, and $510 \mathrm{H}_{\mathrm{V}}$, respectively, are displayed in the $\mathrm{Cu}_{47} \mathrm{Zr}_{43} \mathrm{Al}_{7} \mathrm{Ag}_{3}$ alloy. In addition, from SEM and TEM observations, the crystallization of nano-sized phase aids to disrupt the propagation of shear deformation, to branch the primary shear bands, and to form the secondary shear bands of alloys during plastic deformation. 
Acknowledgments: This work was supported by the National Science Council of Taiwan, under Grant No. NSC102-2221-E-214-016 and MOST 105-2112-M-214-001. In addition, the authors would like to acknowledge the help with the SEM and TEM analyses by the Micro and Nano Analysis Laboratory of I-Shou University.

Author Contributions: T.M.C. designed the experimental procedure; T.M.C., S.R.J., and P.J.H. conducted the experiments and analyzed the data; T.M.C. and P.J.H. performed the analysis tools; P.J.H. wrote the paper.

Conflicts of Interest: The authors declare no conflict of interest.

\section{References}

1. Wang, D.; Li, Y.; Lu, K.; Ma, E. Bulk metallic glass formation in the binary Cu-Zr system. Appl. Phys. Lett. 2004, 84, 4029. [CrossRef]

2. Wang, W.H.; Lewandowski, J.J.; Greer, A.L. Understanding the glass forming ability of $\mathrm{Cu}_{50} \mathrm{Zr}_{50}$ alloy in terms of metastable eutectic. J. Mater. Res. 2005, 20, 2307. [CrossRef]

3. Zhang, T.; Men, H.; Pang, S.J.; Fu, J.Y.; Ma, C.L.; Inoue, A. Effects of a minor addition of Si and/or Sn on formation and mechanical properties of Cu-Zr-Ti bulk metallic glass. Mater. Sci. Eng. A 2007, 295, 449. [CrossRef]

4. Zhang, Q.; Zhang, W.; Inoue, A. New Cu-Zr-based bulk metallic glasses with large diameters of up to $1.5 \mathrm{~cm}$. Scr. Mater. 2006, 55, 711. [CrossRef]

5. Eckert, J.; Das, J.; Kim, K.B.; Wang, W.H.; Zhang, Z.F. High strength ductile Cu-base metallic glass. Intermetallics 2006, 14, 876. [CrossRef]

6. Sha, Z.D.; Feng, Y.P.; Li, Y. Statistical composition-structure-property correlation and glass-forming ability based on the full icosahedra in Cu-Zr metallic glasses. Appl. Phys. Lett. 2010, 96, 61903. [CrossRef]

7. Xu, H.W.; Du, Y.L.; Deng, Y. Effects of Y addition on structural and mechanical properties of CuZrAl bulk metallic glass. Trans. Nonferr. Met. Soc. China 2012, 22, 842. [CrossRef]

8. Lee, J.C.; Kim, Y.C.; Ahn, J.P.; Kim, H.S.; Lee, S.H.; Lee, B.J. Deformation-induced nanocrystallization and its influence on work hardening in a bulk amorphous matrix composite. Acta Mater. 2004, 52, 1525. [CrossRef]

9. Bian, Z.; Kato, H.; Qin, C.L.; Zhang, W.; Inoue, A. Cu-Hf-Ti-Ag-Ta bulk metallic glass composites and their properties. Acta Mater. 2005, 53, 2037. [CrossRef]

10. Kim, K.B.; Das, J.; Venkataraman, S.; Yi, S.; Eckert, J. Work hardening ability of ductile $\mathrm{Ti}_{45} \mathrm{Cu}_{40} \mathrm{Ni}_{7.5} \mathrm{Zr}_{5} \mathrm{Sn}_{2.5}$ and $\mathrm{Cu}_{47.5} \mathrm{Zr}_{47.5} \mathrm{Al}_{5}$ bulk metallic glasses. Appl. Phys. Lett. 2006, 89, 71908. [CrossRef]

11. Eckert, J.; Das, J.; Pauly, S.; Duhamel, C. Processing Routes, Microstructure and Mechanical Properties of Metallic Glasses and their Composites. Adv. Eng. Mater. 2007, 9, 443. [CrossRef]

12. Pauly, S.; Liu, G.; Wang, G.; Eckert, J. Microstructural heterogeneities governing the deformation of $\mathrm{Cu}_{47.5} \mathrm{Zr}_{47.5} \mathrm{Al}_{5}$ bulk metallic glass composites. Acta Mater. 2009, 57, 5445. [CrossRef]

13. Pauly, S.; Bednarcik, J.; Mattern, N.; Kim, D.H.; Eckert, J. Deformation-induced martensitic transformation in Cu-Zr-(Al,Ti) bulk metallic glass composites. Scr. Mater. 2009, 60, 431. [CrossRef]

14. Song, K.K.; Pauly, S.; Zhang, Y.; Scudino, S.; Gargarella, P.; Surreddi, K.B.; Kühn, U.; Eckert, J. Significant tensile ductility induced by cold rolling in $\mathrm{Cu}_{47.5} \mathrm{Zr}_{47.5} \mathrm{Al}_{5}$ bulk metallic glass. Intermetallics 2011, 19, 1394. [CrossRef]

15. Park, E.S.; Kim, D.H. Phase separation and enhancement of plasticity in Cu-Zr-Al-Y bulk metallic glasses. Acta Mater. 2006, 54, 2597. [CrossRef]

16. Pan, J.; Liu, L.; Chan, K.C. Enhanced plasticity by phase separation in CuZrAl bulk metallic glass with micro-addition of Fe. Scr. Mater. 2009, 60, 822. [CrossRef]

17. Kim, Y.C.; Lee, J.C.; Cha, P.R.; Ahn, J.P.; Fleury, E. Enhanced glass forming ability and mechanical properties of new Cu-based bulk metallic glasses. Mater. Sci. Eng. A 2006, 437, 248. [CrossRef]

18. Zhang, Q.; Zhang, W.; Xie, G.; Inoue, A. Formation of a phase separating bulk metallic glass in $\mathrm{Cu}_{40} \mathrm{Zr}_{40} \mathrm{Al}_{10} \mathrm{Ag}_{10}$ alloy. Mater. Sci. Eng. B 2008, 148, 97. [CrossRef]

19. Oh, J.C.; Ohkubo, T.; Kim, Y.C.; Fleury, E.; Hono, K. Phase separation in $\mathrm{Cu}_{43} \mathrm{Zr}_{43} \mathrm{Al}_{7} \mathrm{Ag}_{7}$ bulk metallic glass. Scr. Mater. 2005, 53, 165. [CrossRef]

20. Kündig, A.A.; Ohnuma, M.; Ohkubo, T.; Abe, T.; Hono, K. Glass formation and phase separation in the Ag-Cu-Zr system. Scr. Mater. 2006, 55, 449. [CrossRef]

21. Louzguine-Luzgin, D.V.; Xie, G.; Zhang, W.; Inoue, A. Devitrification behavior and glass-forming ability of Cu-Zr-Ag alloys. Mater. Sci. Eng. A 2007, 465, 146. [CrossRef] 
22. Zhang, W.; Inoue, A. High glass-forming ability and good mechanical properties of new bulk glassy alloys in Cu-Zr-Ag ternary system. J. Mater. Res. 2006, 21, 234. [CrossRef]

23. Louzguine-Luzgin, D.V.; Xie, G.; Li, S.; Zhang, Q.S.; Zhang, W.; Suryanarayana, C.; Inoue, A. Glass-forming ability and differences in the crystallization behavior of ribbons and rods of Cu36Zr48Al8Ag8 bulk glass-forming alloy. J. Mater. Res. 2009, 24, 1886. [CrossRef]

24. Jiang, Q.K.; Wang, X.D.; Nie, X.P.; Zhang, G.Q.; Ma, H.; Fecht, H.-J.; Bendnarick, J.; Franz, H.; Liu, Y.G.; Cao, Q.P.; et al. Zr-(Cu,Ag)-Al bulk metallic glasses. Acta Mater. 2008, 56, 1785. [CrossRef]

25. Sung, D.S.; Kwon, O.J.; Fleury, E.; Kim, K.B.; Lee, J.C.; Kim, D.H.; Kim, Y.C. Enhancement of the glass forming ability of Cu-Zr-Al alloys by Ag addition. Met. Mater. Int. 2004, 10, 575. [CrossRef]

26. Wang, W.H.; Dong, C.; Shek, C.H. Bulk metallic glasses. Mater. Sci. Eng. 2004, R44, 45. [CrossRef]

(C) 2016 by the authors; licensee MDPI, Basel, Switzerland. This article is an open access article distributed under the terms and conditions of the Creative Commons Attribution (CC-BY) license (http:/ / creativecommons.org/licenses/by/4.0/). 